\title{
Biomass Estimation for Four Common Grass Species in Northern Arizona Ponderosa Pine
}

\author{
STEVEN W. ANDARIESE AND W. WALLACE COVINGTON
}

\begin{abstract}
Vegetation allometric relations were examined for 4 important grass species in southwestern ponderosa pine (Pinus ponderosa). Logarithmic regressions were developed relating aboveground biomass to basal area, height, and number of seedheads, as well as 3 factors: overstory type (pole, yellow pine), burning treatment (unburned, prescribed burn 2-, 5-, and 7-yr previously), and site (3 locations). Basal area was defined as longest basal diameter multiplied by the widest perpendicular diameter. Of the metric variables, basal area proved to be the best predictor of biomass. Height and number of seedheads did little to increase $R^{2}$ values. Burning treatment was a significant factor for Situnion longefolium and Muhlenbergia montana. Overstory type significantly affected $P$ oa fenderiana and Festuca arizonica equations. Site effects were important for all but Sitanion longefolium. When biomass regressions are used for species such as these, sampling efficiency can be improved by including factors such as overstory type, burning history, and locale. Final regression equations relating biomass of each species to basal area and significant factors were significant at $p<0.05$ and had adjusted $R^{2}$ values ranging from 0.81 to 0.87 .

$A$ validation test using $20 \%$ of the data not used in developing the regressions indicated that these equations are adequate predictors. When used with double sampling, weight prediction based on basal area indices should provide a more objectively measured predictor than percent cover.
\end{abstract}

Allometric relationships are often used to estimate understory biomass (e.g., Brown and Marsden 1976, Ohmann et al. 1981, Olson and Martin 1981). When compared with harvesting, the application of regression equations based on these relationships can result in lower sampling costs (or higher precision) due to relatively greater sampling efficiency (Reese et al. 1980). Most understory biomass equations are developed using fairly subjective ocular estimates of percent cover as the independent variable. Ocular estimates have the disadvantage of varying between observers as well as over time for a single observer, introducing unknown, but potentially substantial, error into the biomass estimates. We felt that using some combination of basal area, plant height, or number of seedheads might overcome these problems.

A recent study of the effect of prescribed burning on understory production in northern Arizona (Andariese 1982), provided us with the opportunity to test this technique for a ponderosa pinebunchgrass type and to determine if overstory conditions, site, or burning treatment significantly alter the allometric relationship.

\section{Methods}

Three study sites on basalt soils were located on the Coconino National Forest. The overstory at each site was exclusively ponderosa pine (Pinus ponderosa Laws.). The sites were burned during the fall 2, 5, and 7 years before sampling in 1981 .

Sampling in burn and nearby control stands was stratified by overstory type. Pole stands were defined as those dominated by trees $10-30 \mathrm{~cm} \mathrm{dbh}$; yellow pine stands were defined as open, old growth areas dominated by trees greater than $30 \mathrm{~cm} \mathrm{dbh}$.

The 4 most common species were used for evaluating the technique: squirreltail (Sitanion longefolium J.G. Smith), muttongrass (Poa fendleriana (Steud.) Vasey), Arizona fescue (Festuca arizon-

\footnotetext{
Authors are research assistant and associate professor, School of Forestry, Northern Arizona University. Flagstaff 86011.

Manuscript accepted 26 December 1985
}

ica Vasey), and mountain muhly (Muhlenbergia montana (Nutt.) Hitche.). At each site, approximately 20 plants per treatment (burn and control) were selected in pole stands and 15 plants per treatment were selected in yellow pine stands for each species. Data were collected for each species after seedhead production was complete. Muttongrass was collected in late June, Arizona fescue in mid August, squirreltail in late August, and mountain muhly in early September.

Plants were selected to ensure adequate sampling of the range of plant basal areas encountered in the field. Since defining an individual of a bunchgrass is difficult, an individual plant was defined as green plant material with horizontal basal discontinuities no greater than $2.5 \mathrm{~cm}$. For each plant, the longest basal diameter and the widest basal diameter perpendicular to this were recorded to the nearest $0.25 \mathrm{~cm}$. Plant basal area was defined as the product of these 2 diameters. In addition, plant height (extended length of the longest blade) and number of seedheads were recorded. The plant was then clipped at ground level. Samples were returned to the lab and sorted. Green material was dried at $80^{\circ} \mathrm{C}$ to constant weight and weighed to the nearest $0.01 \mathrm{~g}$.

Initially, to determine the best form for the model and to determine the best predictor of plant weight for each species, equations were developed for each site-overstory-treatment combination. Then $80 \%$ of the data were used to develop one final predictive equation for each species; the remaining $20 \%$ were used for validation. To account for variation due to differences in site, overstory type, and treatment, dummy variables representing these factors and their interaction with basal area were entered into each equation using a stepwise procedure (Nie et al. 1975). Only dummy variables with significant $F$ values $(p<0.05)$ were used in the final equations.

To validate each regression equation, it was applied to the remaining $20 \%$ of the data to predict dry weight. The mean squared difference between predicted and observed $\log _{e}$ of dry weight was compared to the residual mean square of the equation (see Snee 1977).

\section{Results and Discussion}

Plant basal area proved to be the best predictor of plant weight for each species. Height and number of seedheads added little to $\boldsymbol{R}^{2}$ values and we felt that the small increase in predictive precision did not justify the increased cost of measuring these plant characteristics. Consequently, they were not included in the final equations. To obtain linearity and constant variance, the linearized form of the allometric equation,

$$
\log _{e} Y=\log _{e} A+B\left(\log _{e} X\right) \text {, }
$$

was used as the model for predictive equations for each species.

Final prediction equations for squirreltail, muttongrass, Arizona fescue, and mountain muhly (Table 1) all exhibited $F$ ratios significant at the 0.05 probability level. Adjusted $R^{2}$ values ranged from 0.81 for muttongrass and squirreltail to 0.87 for Arizona fescue. Corrections for logarithmic bias should be applied to the predictions (Baskerville 1972).

Results of this regression analysis compared favorably with those of other studies. In 14 stands throughout western Montana and northern Idaho, Brown and Marsden (1974) developed regression equations to predict weight per unit area or graminoids (live 
Table 1. Regression equations' of plant basal area in $\mathrm{cm}^{2}(X)$ on plant dry weight in $\mathrm{g}(Y)$ for squirreltail, muttongrass, Arizona fescue, and mountain muhly.

\begin{tabular}{|c|c|c|c|c|}
\hline Species & Equation ${ }^{2}$ & $\mathbf{N}$ & $\mathrm{SEE}^{3}$ & $\frac{R^{2}}{\text { (adjusted) }}$ \\
\hline $\begin{array}{l}\text { Squirreltail } \\
\text { Muttongrass }\end{array}$ & $\begin{aligned} \log _{e} Y= & -0.578+0.453\left(\log _{e} X\right)+0.151(B T) \\
\log _{e} Y= & -1.14+0.602\left(\log _{e} X\right)-0.146(B S 1)+0.083(B S 2) \\
& -0.296(O S)\end{aligned}$ & $\begin{array}{l}171 \\
173\end{array}$ & $\begin{array}{l}0.495 \\
0.515\end{array}$ & $\begin{array}{l}.81 \\
.81\end{array}$ \\
\hline Arizona fescue & $\begin{aligned} \log _{e} \mathrm{Y}=- & 1.12+0.724\left(\log _{e} \mathrm{X}\right)-0.156(\mathrm{BS} 1)-0.128(\mathrm{BS} 2) \\
& -0.302(\mathrm{~S} 2)+0.230(\mathrm{~S} 2)-0.231(\mathrm{OS})\end{aligned}$ & 138 & 0.436 & .87 \\
\hline Mountain muhly & $\begin{aligned} \log _{e} Y=- & 1.26+0.617\left(\log _{e} X\right)+0.008(B S 1)-0.121(B S 2) \\
& +0.166(T)\end{aligned}$ & 169 & 0.456 & .86 \\
\hline
\end{tabular}

'Equations are of the form $\log _{e} Y=a+b\left(\log _{\bullet} X\right)$. Dummy variables are included when significant $(P<.05)$ and are defined as follows: $S 1=1$ if site is 7 yr burn, 0 if otherwise; $S 2=1$ if site is 5 yr burn, 0 if otherwise; $O S=1$ if overstory type is pole, 0 if yellow pine; $T=1$ if treatment is burn, 0 if control; BS1 $=S 1 * \log _{*} X ; B S 2=S 2 * \log , X ;$ and $B T=T * \log _{e} X$. 2All equations are significant at the $P<.05$ level. Corrections for logarithmic bias must be made when using these equations (see Baskerville 1972).

${ }^{3}$ Standard error of the estimate.

and dead material) from percent cover and average height. They reported a relatively low $R^{2}$ value of 0.30 , most likely due to the variety of species and sites included in the analysis. Payne (1974) developed equations to predict dry weight per unit area from percent cover for various species in southwestern Montana. Correlation coefficients for grass species ranged from $0.72\left(R^{2}=0.52\right)$ for Festuca idahoensis Elmer. to $0.97\left(R^{2}=0.94\right)$ for Bromus tectorum L. In northeastern Minnesota, Ohmann et al. (1976) used the standard allometric equation (log-log transformation) to develop regression equations which predicted total above ground biomass from stem diameter for 5 shrubs. They reported $R^{2}$ values that ranged from 0.13 for Corylus cornuta Marsh. to 0.94 for Alnus crispa (Ait.) Pursh.

Dummy variables which proved to be significant $(p<0.05)$ in our study suggest that treatment, overstory type, and site are important in the allometric relationship between basal area and weight for some species. Dummy variables representing treatment were significant in the equations for squirreltail and mountain muhly. Overstory dummy variables were significant in muttongrass and Arizona fescue equations; site dummy variables were significant in muttongrass, Arizona fescue, and mountain muhly equations. These results militate against indiscriminant application of regression equations, even on seemingly similar sites. Overstory conditions, burning history, and local site conditions all should be taken into account to optimize the precision of the technique.

The $R^{2}$ values reported here show that plant basal area is a good predictor of plant weight for 4 common grass species. In addition, the mean square difference between predicted and observed $\log _{e}$ of dry weight was in close agreement with the residual mean square of the regression equation (Table 2), indicating the equations made

Table 2. Mean square difference between predicted and observed logo of dry weight for $20 \%$ of the data not used in predictive equations and residual mean square for each regression equation.

\begin{tabular}{lcc}
\hline \hline & $\begin{array}{c}\text { Mean Square } \\
\text { Difference Predicted } \\
\text { vs Observed }\end{array}$ & $\begin{array}{c}\text { Residual Mean } \\
\text { Square Regression } \\
\text { Equation }\end{array}$ \\
\hline Squirreltail & .259 & .245 \\
Muttongrass & .507 & .265 \\
Arizona fescue & .265 & .190 \\
Mountain muhly & .250 & .208 \\
\hline
\end{tabular}

accurate predictions of independent data (see Snee 1977). We feel that when biomass estimates of these species are required, sampling efficiency can be improved with the use of double sampling (Reese et al. 1980) and predictive equations such as those presented here. (Double sampling differs from our method however, in that it assumes random sampling as opposed to plant selection based on basal area.) Furthermore, the basal area diameters are more objectively measured prediction variables than the most traditional percent cover estimations, which vary substantially from observer to observer and even with observer among sampling dates. Thus, the use of plant basal area should obviate this considerable limitation in the widely used double sampling technique.

\section{Literature Cited}

Andariese, S.W. 1982. Time response graphs for understory production following fall prescribed burning in Arizona ponderosa pine on basalt soils. M.S.F. Thesis, Northern Arizona Univ., Flagstaff.

Baskerville, G.L. 1972. Use of logarithmic regression in estimation of plant biomass. Can. J. Forest. 2:49-53.

Brown, J.K., and M.A. Marsden. 1976. Estimating fuel weights of grasses, forbs, and small woody plants. USDA Forest Serv. Res. Note. INT-210.

Nie, N.H., C.H. Hull, J.G. Jenkins, K. Steinbrenner, and D.H. Brent. 1975. SPSS: statistical package for the social sciences. 2nd ed. McGraw-Hill Book Company, New York, N.Y.

Ohmann, L.F., D.F. Grigal, and R.B. Brander. 1976. Biomass estimation for 5 shrubs from northeastern Minnesota. USDA Forest Serv. Res. Pap. NC-133.

Ohmann, L:F., D.F. Grigal, and L.L. Rogers. 1981. Estimating plant biomass for undergrowth species of northeastern Minnesota. USDA Forest Serv. Gen. Tech. Rep. NC-61.

Olson, C.M., and R.E. Martin. 1981. Estimating biomass of shrubs and forbs in central Washington Douglas-fir stands. USDA Forest Serv. Res. Note PNW-380.

Payne, G.F. 1974. Cover-weight relationships. J. Range Manage. 27:403-404.

Reese, G.A., R.L. Bayn, and N.E. West. 1980. Evaluation of doublesampling estimators of subalpine herbage production. J. Range manage. 33:300-306.

Snee, Ronald D. 1977. Validation of regression models: methods and examples. Technometrics 19:415-428. 